\title{
Evaluation of Terbinafine Activity on Pneumocystis carinii in the Rat Model
}

\author{
Pneumocystis carinii'ye Terbinafinin Etkisinin Rat Modelinde Değerlendirilmesi \\ Müge Oğuzkaya ARTAN ${ }^{1}$, Nedret KOÇ², Ahmet ÖZTÜRK \\ ${ }^{1}$ Erciyes Üniversitesi, Sağllk Hizmetleri Meslek Yüksekokulu, Kayseri \\ ${ }^{2}$ Erciyes Üniversitesi, Tip Fakültesi Mikrobiyoloji Anabilim Dal, ${ }^{3}$ Biyoistatistik Anabilim Dalı, Kayseri
}

Submitted / Başvuru tarihi: 22.12.2008 Accepted / Kabul tarihi: 09.02.2009

Objective: The purpose of this study was to test the hypothesis thThis study was planned to investigate the antipneumocystis activity of terbinafine in a rat model.

Material and Methods: Rats were obtained from the Hakan Çetinsaya Experimental and Clinical Research Institutions, Erciyes University, Kayseri, Turkey. Terbinafine administered orally in doses of $40,80,120$ and $160 \mathrm{mg} / \mathrm{kg} /$ day after nine weeks of immunosuppression with dexamethasone to facilitate the development of acute Pneumocystis carinii penumoniae (PCP).

Results: Untreated animals showed $P$. carinii infection levels with a mean ( \pm standard deviation) log number of cysts per gram of lung tissue of $4.6 \pm 1.6$ at the end of the experiment. Terbinafine administered at a dose of $160 \mathrm{mg} / \mathrm{kg} /$ day significantly reduced the log number of cysts per gram to $2.2 \pm 1.5$. The therapeutic efficacy of terbinafine administered at $160 \mathrm{mg} / \mathrm{kg} /$ day $(\log 2.2 \pm 1.5$ cysts/lung) was similar to that obtained with trimethoprim-sulfamethoxazole (TMP-SMX), 50/250 mg/kg/ day $(p<0.001)$. A reduction in the number of cysts was also observed in infected animals treated with 80 , and $120 \mathrm{mg}$ of terbinafine $/ \mathrm{kg} / \mathrm{day}$, although the results were not statistically significant ( $p>0.05)$.

Conclusion: In our model, the efficacy of terbinafine in PCP has been found to be dose dependent.

Key words: Pneumocystis carinii; rat; terbinafine.
Amaç: $\mathrm{Bu}$ çalışma rat modelinde terbinafinin antiPneumocystis aktivitesini belirlemek için planlanmıştır.

Gereç ve Yöntemler: Ratlar Erciyes Üniversitesi Deneysel ve Klinik Araştırma Merkezin'den sağlanmıştır. Dokuz hafta boyunca akut Pneumocystis carinii pnömonisi (PCP) oluşturmak üzere, deksamethazon ile immünsüpresyon yapilan ratlara oral olarak 40,80, 120 ve 160 $\mathrm{mg} / \mathrm{kg} / \mathrm{gün}$ terbinafin verildi.

Bulgular: Çalışmanın sonunda tedavi almayan grupda PCP enfeksiyon düzeyi ortalama ( \pm standart sapma)

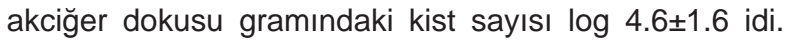
Terbinafin $160 \mathrm{mg} / \mathrm{kg} / \mathrm{gün}$ uygulanan grupta gramdaki kist sayısında önemli düşüş gözlendi log 2.2ะ1.5. Terbinafin $160 \mathrm{mg} / \mathrm{kg} / \mathrm{gün}$ uygulanan tedavi etkinliği, trimetoprim-sulfametoksazol (TMP-SMX), $50 / 250 \mathrm{mg} /$ $\mathrm{kg} /$ gün uygulaması ile benzer sonuç verdi $(p<0.001)$. Terbinafin 80 ve $120 \mathrm{mg} / \mathrm{kg} / \mathrm{gün}$ uygulamalarında da kist sayısında düşüş görülmekle birlikte bu değerler istatistiksel olarak anlamlı değildi $(p>0.05)$.

Sonuç: Bizim modelimizde terbinafinin PCP etkinliği doza bağlı bulundu.

Anahtar sözcükler: Pneumocystis carinii; rat modeli; terbinafin.

XXII. International Congress of Mycology 5-9 Agust 2008, istanbul.

Correspondence (iletişim adresi): Dr. Müge Oğuzkaya Artan. Erciyes Üniversitesi, Sağlık Hizmetleri Meslek Yüksekokulu, Kayseri, Turkey. Tel: 03524374901 e-mail (e-posta): martan38@gmail.com

(C) Trakya Üniversitesi Tıp Fakültesi Dergisi. AVES Yayıncılık tarafından basılmıştır. Her hakkı sakıdır.

() Medical Journal of Trakya University. Published by AVES Publishing. All rights reserved. 
Pneumocystis is a leading cause of pneumonia in patients with immune deficiencies, including individuals infected with human immunodeficiency virus (HIV) and those receiving chemotherapy for malignancies or for transplantation. Drugs used in PCP in clinical use are hampered by toxicity, limited effectiveness, and emerging resistance. ${ }^{[1,2]}$ The lack of interest among pharmaceutical companies in developing new agents for Pneumocystis has stimulated efforts to test existing drugs marketed for other purposes for activity against the organism. Terbinafine is an allylamine antifungal agent which appears to act by preventing fungal ergosterol biosynthesis via specific and selective inhibition of fungal squalene epoxidase. ${ }^{[3]}$ Terbinafine is currently indicated for the treatment of superficial dermatophyte and yeast infections. There are also data to suggest that terbinafine may be effective in treating histoplasmosis, Pneumocytis infection, fungal mycetoma, and cutaneous leishmaiasis. ${ }^{[4]}$

The investigators of two studies found that terbinafine given at oral doses of 15 to $80 \mathrm{mg} / \mathrm{kg} /$ day had an efficacy equal to or greater than that of known anti$P$. carinii drugs in rats with $\mathrm{PCP}^{[5,6]}$ In another study Walzer et al. $^{[1]}$ showed that terbinafine administered orally at doses of 20 to $400 \mathrm{mg} / \mathrm{kg} /$ day and 50 to 250 $\mathrm{mg} / \mathrm{kg} /$ day was ineffective therapy for mouse and rat models of pneumocystosis, respectively.

In the present study, we evaluate the terbinafine activity of experimental pneumocystosis by determining the $P$. carinii cyst counts.

\section{MATERIALS AND METHODS}

Male Sprague-Dawley rats (weight, 200 to $250 \mathrm{~g}$ ) obtained from Hakan Çetinsaya Experimental and Clinical Research Institutions, Kayseri, were used in the study. The animals were housed at room temperature $\left(20 \pm 2{ }^{\circ} \mathrm{C}\right)$ in standard cages with food of regular rodent chow (23\% protein), and water ad libitum and kept under controlled environmental conditions following the standard operating procedures of the Institution. The approval of the Animal Ethics Committee was obtained. Animals were immunosuppressed with $2 \mathrm{mg}$ of dexamethasone per liter in the drinking water during 9 weeks to facilitate the development of acute PCP. Tetracycline $(1 \mathrm{mg} / \mathrm{lt})$ was added to the drinking water to minimize bacterial infections. ${ }^{[7-9]}$ All animals remained on immunosuppression therapy with dexamethasone throughout the study. Food and water were ad libitum. The rats were distributed into six groups of 10 animals per group. Two rats were sacrificed at the initiation of the study to confirm the presence of $P$. carinii pneumonia. Terbinafine (Fako, İstanbul, Turkey) was administered at doses of 40,80,120, and $160 \mathrm{mg} / \mathrm{kg} /$ day. One known antipneumocystis agent TMP-SMX (50/250 mg/ $\mathrm{kg} /$ day) was used as the positive control in the study. The drugs to be tested were given by oral gavages on a milligram-per-kilogram basis in a single dose for 10 consecutive days. Control animals receiving steroids (C/S group) were administered no drug. The rats were observed daily for appearance, activity, and food and water consumption. Efficacy was based on the organism burden in the treatment groups with that in the control group (C/S). In our model, drug effectiveness was based on organism burden rather than survival because the animals die sometimes from causes (e.g. other opportunistic infections) other than $P$. carinii infection. ${ }^{[1,10]}$ At the end of the treatment period, the animals were fasted overnight and sacrificed. The right lung was removed, and cut into small pieces in a sterile phosphate-buffered saline solution, and homogenized. Cell debris was removed by filtering the homogenate through sterile gauze. The filtrate was centrifuged at 2,900 X $\mathrm{g}$ for $10 \mathrm{~min}$, and the pellet was resuspended in phosphate-buffered saline, and stained with cresyl echt violet, which selectively stains the cell wall of the cyst. ${ }^{[7,8,10]}$ The number of cysts was determined by visual assessment under light microscope (20 microscopic fields).

\section{Statistical Analysis}

Data were expressed as mean \pm standard deviation. Comparison of drug efficacy between groups was made by using the Kruskal-Wallis one way analysis of variance on Rank test (KW). Post-hoc comparisons on parameters were performed using Dunn's procedure. Statistical significance was set at $p<0.05$. All analyses were performed with the statistical package for scientist (SIGMASTAT) Windows version 3.10.

\section{RESULTS}

The therapeutic efficacy of terbinafine was studied in a rat model of pneumocystosis. Corticosteroid-treated rats showed physical signs of PCP (e.g. loss of weight, cyanosis etc.). Untreated animals showed P. carinii infection levels with a mean \pm standard deviation log number of cysts per gram of lung tissue of $4.6 \pm 1.6$ at the end of the experiment. The therapeutic effect of terbinafine was estimated by the reduction in the number of cysts from the lungs of treated versus untreated rats. Terbinafine administered at a dose of $160 \mathrm{mg} / \mathrm{kg}$ / day significantly reduced the $\log$ number of cysts per gram to $2.2 \pm 1.5$. The therapeutic efficacy of terbinafine administered at $160 \mathrm{mg} / \mathrm{kg}$ / day (log $2.2 \pm 1.5$ cysts/lung) was similar to that obtained with TMP-SMX, 50/250 mg/kg/day ( $<<0.001)$. A reduction in the number of cysts was also observed in infected animals treated with 80 , and $120 \mathrm{mg}$ of terbinafine $/ \mathrm{kg}$ / day, although the results were not statistically significant (Table 1). In rats administered terbinafine at 40, 80, 120 $\mathrm{mg} / \mathrm{kg} /$ day, the reduction in log of cyst level were 0.5 , $0.7,0.8$, respectively, relative to those in control animals.

\section{DISCUSSION}

In HIV patients and other immunocompromised hosts, pneumonia caused by Pneumocystis remains an 
Table 1. Efficacy of terbinafine against pneumocystosis in rats.

\begin{tabular}{lccc}
\hline Compounda & $\begin{array}{c}\text { Dose } \\
(\mathrm{mg} / \mathrm{kg} / \text { day })\end{array}$ & $\begin{array}{c}\text { Log10 no. of } \\
\text { cysts/g of lung }\end{array}$ & $\begin{array}{c}\text { Reduction } \\
\text { in log }\end{array}$ \\
\hline Control & & $4.6 \pm 0.3$ & \\
TMP-SXT & $50 / 250$ & $1.8 \pm 1.6^{*}$ & 2.8 \\
Terbinafine & 40 & $4.1 \pm 0.1$ & 0.5 \\
& 80 & $3.9 \pm 0.1$ & 0.7 \\
& 120 & $3.8 \pm 0.2$ & 0.8 \\
& 160 & $2.2 \pm 1.5^{*}$ & 2.4 \\
\hline
\end{tabular}

${ }^{a}$ Compounds were administered by oral gavages every $24 \mathrm{~h}$ for 10 consecutive days. ${ }^{*}$, p value of $<0.001$ for mean log of cysts in treated versus control group by Kruskal-Wallis one way analysis of variance on Rank test $(\mathrm{KW})$. Values are means \pm standard deviation.

important clinical problem in contravention of improved treatment strategies. The lack of interest among pharmaceutical companies in developing new agents for Pneumocystis has stimulated efforts to test existing drugs, marketed for other purposes, for activity against the organism. ${ }^{[11-13]}$ Terbinafine is an allylamine agent which appears to act by preventing fungal ergosterol biosynthesis via specific and selective inhibition of fungal sequalene epoxidase..$^{[3,4]}$ It is orally and topically active especially on dermatophyte, filamentous, dimorphic and dematiaceous fungi, and some yeast species. There are also data to suggest that terbinafine may be effective in treating histoplasmosis, Pneumocystis infection, fungal mycetoma, and cutaneous leishmaiasis. ${ }^{[4-6]}$ The present study has shown that, in our rat model of pneumocystosis, Terbinafine had a dose dependent activity. Walzer et al. ${ }^{[1]}$ studied the usage of terbinafine in mouse and rat models of PCP. In the mouse model they were administered terbinafine $20,50,150,400 \mathrm{mg} / \mathrm{kg}$ /day and, when compared with the control group, there were no statistically differences, just like the rat model. The investigators then suggested that terbinafine is ineffective as treatment in their mouse and rat models of PCP. In another study Conti et al. ${ }^{[6]}$ using Sprague-Dawley rats with experimentally induced PCP, terbinafine at doses of $40 \mathrm{mg}$ and $80 \mathrm{mg} / \mathrm{kg}$ bodyweight/day was compared to atovaquone $100 \mathrm{mg} / \mathrm{kg} /$ day, albendazole 600 $\mathrm{mg} / \mathrm{kg} /$ day, TMP-SXT 12.5 and $62.5 \mathrm{mg} / \mathrm{kg} /$ day and control (rats treated only with cortisone acetate $25 \mathrm{mg}$ twice weekly subcutaneously). Treatment duration was 5 weeks, with $n=15$ in each group. The results showed that terbinafine is as effective as TMP-SXT in clearing $P$. carinii infection and in reducing histological scores, and more effective using these parameters than either atovaquone or albendazole. In our model, only $160 \mathrm{mg}$ terbinafine $\mathrm{kg}$ bodyweight/day was found as effective as TMP-SXT. The other administered doses were ineffective (Table 1). The only explanation for these conflicting results reported here and by the other investigators may be the presence of species or strain differences in the $P$. carinii infecting animal colonies. ${ }^{[1,6]}$
These conflicting results on terbinafine against Pneumocystis emphasizes the complexities of Pneumocystis drug testing and the need for the results obtained by one group to be confirmed by others before considering studies in humans.

\section{Acknowledgement}

This study was supported by the Erciyes University Scientific Research Unit.

\section{Conflict of Interest}

No conflict of interest declared by the authors.

\section{REFERENCES}

1. Walzer PD, Ashbaugh A: Use of terbinafine in mouse and rat models of Pneumocystis carinii pneumonia. Antimicrob Agents Chemother 2002;46:514-6.

2. Bartlett MS, Angus WC, Shaw MM, Durant PJ, Lee CH, Pascale JM, et al. Antibody to Pneumocystis carinii protects rats and mice from developing pneumonia. Clin. Diagnogn. Lab Immunol 1998;5:74-7.

3. Balfour JA, Faulds D: Terbinafine. A review of pharmacodynamics and pharmacokinetic properties, and therapeutic potential in superficial mycoses. Drugs 1992;43:259-84.

4. Hay RJ: Therapeutic potential of terbinafine in subcutaneous and systemic mycoses. Br J Dermatol 1999;141:36-40.

5. Contini C, Manganaro M, Romani R, Tzantzoglou S, Poggesi I, Vullo V, et al. Activity of terbinafine against Pneumocystis carinii in vitro and its efficacy in the treatment of experimental pneumonia. J Antimicrob Chemother 1994;34:727-35.

6. Contini C, Colombo D, Cultrera R, Prini E, Sechi T, Angelici E, et al. Employment of terbinafine against Pneumocystis carinii infection in rat models. Br J Dermatol 1996;134:30-2.

7. Kim CK, Foy JM, Cushion MT, Stanforth D, Linke MJ, Hendrix HL, et al. Comparison of histologic and quantitative tecniques in evaluation of therapy for experimental Pneumocystis carinii pneumonia. Antimicrob Agents Chemother 1987;31:197-201.

8. Martinez A, Aviles P, Jimenez E, Caballero J, GargalloViola D. Activities of sordarins in experimental models of candidiasis, aspergillosis, and pneumocystosis. Antimicrob Agents Chemother 2000;44:3389-94.

9. Jimenez E, Martínez A, Aliouat el M, Caballero J, Dei-Cas E, Gargallo-Viola D. Therapeutic efficacies of GW471552 and GW471558, two new azasordarin derivatives, against pneumocystosis in two immunosuppressed-rat models. Antimicrob Agents Chemother 2002;46:2648-50.

10. Walzer PD, Runck J, Orr S, Foy J, Steele P, White M. Clinically used antimicrobial drugs against experimental pneumocystosis, singly and in combination:analysis of drug interactions and efficacies. Antimicrob Agents Chemother 1997;41:242-50.

11. Fishma,n JA. Treatment of infection due to Pneumocystis carinii. Antimicrob Agents Chemother 1998;42:1309-14.

12. Kazanjian P, Armstrong W, Hossler PA, Burman W, Richardson J, Lee CH, et al. Pneumocystis carinii mutations are associated with duration of sulfa or sulfone prophylaxis exposure in AIDS patients. J Infect Dis 2000;182:551-7.

13. Walker DJ, Wakefield AE, Dohn MN, Miller RF, Baughman RP, Hossler PA et al. Sequence polymorphism in the Pneumocystis carinii cytochrome b gene and their association with atovaquone prophylaxis failure. J Infect Dis 1998;178:1767-75. 